\title{
Agro-economic evaluation of potassium application in spring maize under early and late sown conditions
}

\author{
I. Ahmad ${ }^{1 *}$ and M. Akram² \\ ${ }^{I}$ Soil Conservation Group of Agriculture Department Mohalla Cha Berriwala, Opposite Deyar-e-Arqam School System Shah \\ Doula Road, Gujrat, Pakistan \\ ${ }^{2}$ Department of Environmental Science, COMSAT Institute of Information Technology, Vehari, Pakistan
}

\begin{abstract}
Although the yield potential of spring maize is much higher than autumn maize but high temperature at anthesis stage is one of the main problems in spring maize especially in late sown conditions which caused a synchronous pollination, fertilization and grain formation. Early sowing of the crop seems an ideal solution to escape the heat period but low temperature causes poor seedling establishment. Both temperature extremes osmotic and oxidative stresses are major reasons of economical crop damage. Potassium application may lessen these oxidative damages and crop stand establishment of maize under semi arid conditions of Faisalabad. Observations on number of plants per unit area, cobs per plant, grains per cob, 100-grain weight, grain yield, grain protein and oil contents were recorded by using standard procedures. The net income and benefit cost ratio were calculated to evaluate the most economical and profitable potassium level. Sowing dates affected significantly number of plants, cobs per plant, grains and 100-weight, grain yield, grain protein and oil contents while potassium application considerably improved grain yield through increasing crop stand under both early and late sown conditions by ameliorating stresses. It is concluded that the benefit cost ratio of $100 \mathrm{~kg} \mathrm{ha}^{-1}$ potassium application is only beneficial under early planting on 1 st February.
\end{abstract}

Key Words: Potassium; Grain yield; Cost benefit ratio; Heat stress

\section{Introduction}

Maize is one of the important cereals and ranks third positions in Pakistan. It is grown in two seasons i.e. spring and autumn. However, the yield potential of spring crop is much higher than autumn sown crop but high temperature at anthesis is a severe constraint to achieve its yield potential. Notably the separation of male and female floral organs and the near-synchronous development of florets on a single plant and extremely sensitive to high temperature accompanied with moisture stress during anthesis (Johnson and Herrero, 1981). Prasad and Staggenborg (2008) reported that high temperature may limit crop growth and yield while Harrison et al., (2011) reported that warm temperature accelerate development and shorten growth period which ultimately reduce the number as well as size of grain in maize. Grain yield of corn reduces on exposure to day time temperature of $38^{\circ} \mathrm{C}$ for $16 \mathrm{~h}$ (Mitchell and Petolino, 1988). High temperature also decreases seed filling duration, which results in shriveled grain and lower seed yield of sorghum (Chowdhary and Wardlaw, 1978; Johnson and Herrero, 1981) and pollen desiccation (Schoper et al., 1986). High temperature (above $38^{\circ} \mathrm{C}$ ) along with water stress occurring at same time decrease kernel set under dry land environments (Ramadoss et al., 2004). So it leads to the idea of early sowing of spring maize crop to avoid heat period during anthesis and seed maturity. Early sowing can contribute to increase grain yield of maize but it required cold tolerance (Rodriguez et al., 2007; Greaves, 1996). Poor and erratic germination at suboptimal temperature is main hindrance in its early planting (Stewart et al., 1990; Ahmad et al., 2015). Maize seeds sown at a soil temperature $10^{\circ} \mathrm{C}$ or below are often injured by cold water imbibitions stress (Cohn and Obendorf, 1978). Moreover, low temperature may induce chilling injury through production of reactive oxygen species (ROS) (Apel and Hirt, 2004), which cause oxidative damage to various macromolecules, cellular structures (Noctor and Foyor, 1998) and important functional units especially photosynthetic apparatus which is susceptible to negative effects of low temperature (Janda et al., 1994; Ahmad et al., 2015 ) which may induce chilling stress below $12-15^{\circ} \mathrm{C}$ (Hola et al., 2003).

Potassium $\left(\mathrm{K}^{+}\right)$is not only a framework or protoplasmic element but indispensable for maintenance of water status, energy balance and cell turgor pressure which is essential in

\footnotetext{
*Corresponding author e-mail: ijazscogujrat@gmail.com
} 
osmoregulation of plant cell, translocation of photosynthates and assists in opening and closing of stomata (Mengal and Kirkby, 1987), essential for activation (Tisdale et al., 1990) and stabilization of enzymes (Balasubramian and Palaniappan, 2001). It regulates photosynthesis, nutrient uptake, assimilate transport and enzyme activation for protein synthesis (Meille and Pellerin, 2008). In water relations, potassium regulates cellular turgor pressure to avoid wilt, in turn controlling the regulation of stomatal opening and closing and greatly enhancing drought and frost tolerance in plants (Kemmler and Krauss, 1987). Its application has promotive effect on growth and development (Brar and Singh, 1995) and grain yield in maize (Davis et al., 1996). The beneficial role of potassium in mitigating the adverse effects of extreme temperatures on various crops has been well documented. Spring maize is sensitive to both low (Rodriguez et al., 2007) and high temperatures (Johnson and Herrero, 1981). Therefore, a study was conducted to optimized potassium level for yield and its economic evaluation of spring hybrid maize by elevating oxidative stress tolerance under early and late sown conditions.

\section{Materials and methods}

The experiment was carried out in randomized complete block design (RCBD) with split plot arrangement randomizing the sowing dates i.e.1st February (Early), 22nd February (Mid) and 15th March (Late) in main plots and levels of potassium $\left(0,100\right.$ and $\left.200 \mathrm{~kg} \mathrm{ha}^{-1}\right)$ in sub-plots using three replications at latitude of $31.26^{\circ} \mathrm{N}$, longitude of $73.06^{\circ} \mathrm{E}$ and altitude of $184.4 \mathrm{~m}$ using hybrid maize ( $\mathrm{Hi}$ Sawn 9697). Meteorological data on the mean maximum/minimum temperatures was recorded at the Department of Crop Physiology, University of Agriculture, Faisalabad during 2008 (Fig. 1). Field experiments were carried out at Research Area Department of Plant Breeding and Genetics, University of Agriculture, Faisalabad (Pakistan). The soil of the experimental area was analyzed for its various physico-chemical properties. The experiment was conducted on loamy soil with organic matter $(0.964 \%)$, $\mathrm{pH}$ (7.41), ECe (0.409), available K (374.49 ppm), available $\mathrm{P}(13.93 \mathrm{ppm})$ and saturation percentage $(36.11 \%)$ at the depths of $0-15 \mathrm{~cm}$ and organic matter $(0.358 \%), \mathrm{pH}(7.40)$, ECe (0.358), available K (326.69 ppm), available P (11.78 $\mathrm{ppm})$ and saturation percentage $(34.53 \%)$ at the depths of $16-30 \mathrm{~cm}$. The soil samples were analyzed for organic matter (Ryan et al., 2001), available phosphorus (Olsen and Sommers, 1982), exchangeable potassium (Knudsen et al., 1982), total nitrogen (Tecator, 1981), ECe (1:2.5 soil- $\mathrm{H}_{2} \mathrm{O}$ mixture) (Rhoades, 1982) and $\mathrm{pH}$ (1:2.5 soil- $\mathrm{H}_{2} \mathrm{O}$ mixture) (McLean, 1982). The net plot size was kept $3.6 \mathrm{~m}$ x $8.0 \mathrm{~m}$. The crop was sown at $60 \mathrm{~cm}$ apart rows at respective sowing dates and two seeds were dibbled at $15 \mathrm{~cm}$ apart hole. The NP @ $200 \& 100 \mathrm{Kg} \mathrm{ha}^{-1}$ in the form of Urea and DAP while K as Sulphate of Potash (SOP) as per treatment was applied. Half of the total dose of nitrogen and full dose of phosphorus and potassium were applied at the time of sowing as basal dose while remaining half dose of nitrogen was top dressed with first irri All other agronomic practices were kept normal and uniform for all treatments. Data on grain yield and its components like number of plants per unit area, cobs per plant, grains per cob, 100-Grain weight (g) and grain yield $\left(\mathrm{Mg} \mathrm{ha}^{-1}\right)$ were recorded by using standard procedures at maturity.

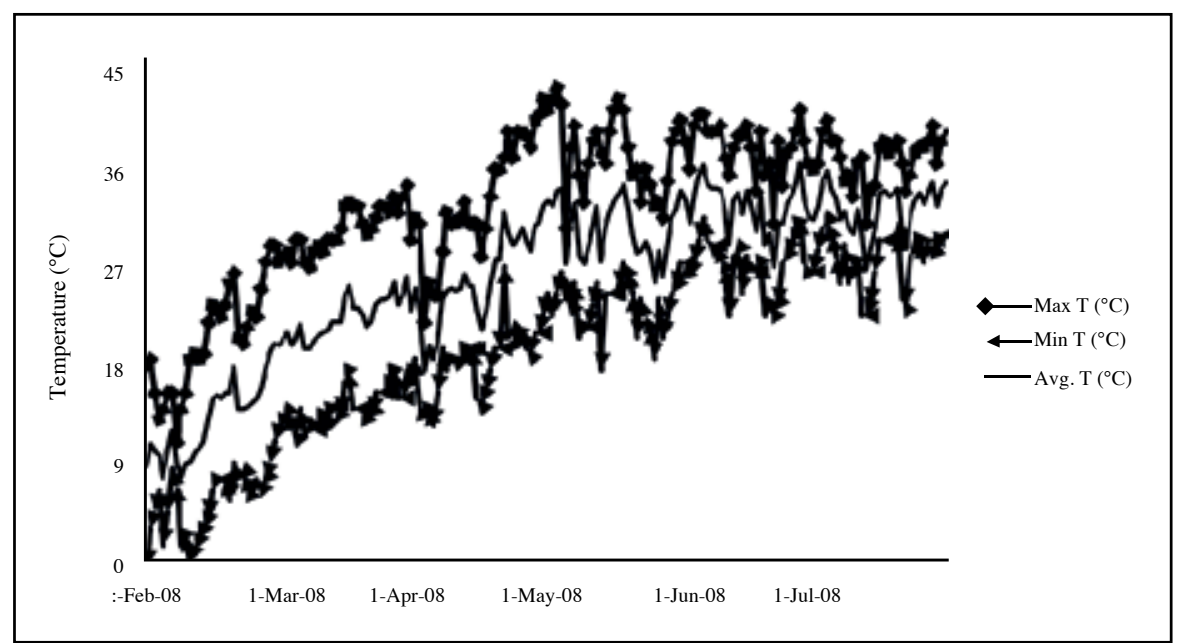

Fig. 1. Daily mean minimum, maximum and average temperature from 1st Feb, 2008 to 31 st July, 2008 at Latitude of $31.26^{\circ} \mathrm{N}$, Longitude of $73.06{ }^{\circ} \mathrm{E}$ and Altitude of $184.4 \mathrm{~m}$ 
For determination of protein contents, 500 seeds from each plot were taken and ground. The digestion was done by Gunning and Hibhards Methods of $\mathrm{H}_{2} \mathrm{SO}_{4}$ and distillation was made with Microjeldhal Apparatus (Jackson, 1962) to determine nitrogen contents in seeds. Thereafter protein contents in seed were calculated by multiplying total nitrogen in the seed with constant factor 5.71 (Peter and Young, 1980).

Dried seeds (100 g) of each experimental unit were crushed and fed to Soxhlet extractor fitted with one liter round bottom flask and a condenser. The extraction was executed with 0.5 $\mathrm{L}$ of $\mathrm{n}$-hexane on water bath for 6-7 h. The solvent was distilled off under vacuum in a rotatory evaporator and percentage of oil was recorded. Maize grain oil contents were found by Soxhlet method as determined by Low (1990).

Economic Analysis: For economic point of view the cost of production of maize crop was calculated planted under early and late sown conditions. The net income and benefit cost ratio was also calculated by the methodology of CYMMIT (1988) to evaluate the most economical, profitable potassium level.

Statistical Analysis: The data collected were analyzed statistically using Fisher's analysis of variance technique and treatment means showing F-values significant were compared by using least significance difference test at 0.05 probability levels (Steel et al., 1997).

\section{Results and discussion}

Crop stand per unit area is the key factor of production because better crop establishment and optimum plant population is essential to get maximum yield. The data indicated that sowing dates affected crop stand at harvesting (Table I). Maximum plant population (10.11 plants $\mathrm{m}^{-2}$ ) was observed in optimum and late planted crop while minimum (9.11 plants $\mathrm{m}^{-2}$ ) during the early planted crop. It is inferred that cob number is an important yield determinant. Potassium fertilization significantly improved cobs per plant significantly. Application of $200 \mathrm{~kg} \mathrm{ha}^{-1}$ potassium resulted in highest number of cobs per plant (1.24) and was statistically at par with those plots fertilized with potassium @ $100 \mathrm{~kg}$ $\mathrm{ha}^{-1}$ which in turn gave 1.24 cobs per plant, while minimum number of cobs per plant (1.04) was recorded from controlled plot (Table I). The interaction effect of sowing dates and potassium levels was found non-significant. The data indicated that grains number per cob was significantly affected by sowing dates. Optimum sowing date (22nd Feb) produced more grains per cob (444) which was statistically similar to early planted maize (1st Feb) while late planting gave less number of grains per cob (355.78). Number of grains per cob was affected significant with various levels of potassium application. Plots fertilized with potassium @ 200 and $100 \mathrm{~kg} \mathrm{ha}^{-1}$ produced the greatest number of grains per cob of 432.22 and 423.22 respectively, while unfertilized plot yielded 368.22 grains per cob (Table I). The interaction effect of both factors found non-significant. A perusal of data revealed that sowing dates caused significant difference in 100-grain weight (Table I). Plant established as result of early planting (1st Feb) produced higher hundred grain weight of $28.44 \mathrm{~g}$, optimum (22 $2^{\text {nd }}$ Feb) sowing date attain the lower 100-kernel weight of $27.35 \mathrm{~g}$ while the late sowing (15th

Table I. Plants per unit area, cobs per plant, grains per cob and 100-grain weight, grain yield, grain protein and grain oil contents of spring sown maize as influenced by different levels of potassium application under early and late sown conditions.

\begin{tabular}{lccccccc}
\hline Treatments & $\begin{array}{c}\text { Plants per } \\
\mathrm{m}^{-2}\end{array}$ & $\begin{array}{c}\text { Cobs per } \\
\text { plant }\end{array}$ & $\begin{array}{c}\text { Grains } \\
\text { per cob }\end{array}$ & $\begin{array}{c}\text { 100-grain } \\
\text { weight }(\mathrm{g})\end{array}$ & $\begin{array}{c}\text { Grain yield } \\
\left(\mathrm{Mg} \mathrm{ha}^{-1}\right)\end{array}$ & $\begin{array}{c}\text { Grain protein } \\
\text { contents }(\%)\end{array}$ & $\begin{array}{c}\text { Grain oil } \\
\text { contents }(\%)\end{array}$ \\
\hline Sowing dates & & & & & & & \\
1st February & $9.11 \mathrm{~b}$ & 1.20 & $423.89 \mathrm{a}$ & $28.44 \mathrm{a}$ & $4.52 \mathrm{~b}$ & $8.05 \mathrm{a}$ & $4.31 \mathrm{a}$ \\
22ndFebruary & $10.11 \mathrm{a}$ & 1.20 & $444.00 \mathrm{a}$ & $27.35 \mathrm{~b}$ & $5.08 \mathrm{a}$ & $7.91 \mathrm{~b}$ & $4.19 \mathrm{a}$ \\
15th March & $10.11 \mathrm{a}$ & 1.13 & $355.78 \mathrm{~b}$ & $25.73 \mathrm{c}$ & $4.05 \mathrm{c}$ & $7.79 \mathrm{c}$ & $4.07 \mathrm{~b}$ \\
LSD at 0.05 & 0.157 & 0.249 & 58.97 & 0.574 & 0.072 & 0.414 & 0.117 \\
Potassium levels $\left(\mathrm{kg} \mathrm{ha}^{-1}\right)$ & & & & & & & \\
Control & $9.00 \mathrm{~b}$ & $1.04 \mathrm{~b}$ & $368.22 \mathrm{~b}$ & $26.14 \mathrm{~b}$ & $4.02 \mathrm{~b}$ & $7.74 \mathrm{c}$ & $4.12 \mathrm{c}$ \\
100 & $10.00 \mathrm{a}$ & $1.24 \mathrm{a}$ & $423.22 \mathrm{a}$ & $27.21 \mathrm{a}$ & $4.79 \mathrm{a}$ & $7.94 \mathrm{~b}$ & $4.19 \mathrm{~b}$ \\
200 & $10.33 \mathrm{a}$ & $1.24 \mathrm{a}$ & $432.22 \mathrm{a}$ & $28.17 \mathrm{a}$ & $4.83 \mathrm{a}$ & $8.07 \mathrm{a}$ & $4.27 \mathrm{a}$ \\
LSD at 0.05 & 0.385 & 0.202 & 24.13 & 0.993 & 0.046 & 0.065 & 0.056 \\
Interaction of both factors & $\mathrm{NS}$ & $\mathrm{NS}$ & $\mathrm{NS}$ & $\mathrm{NS}$ & 0.080 & $\mathrm{NS}$ & $\mathrm{NS}$ \\
\hline
\end{tabular}

Figures sharing same letters did differ significantly at $0.05 \mathrm{p}$. 
March) resulted to lowest 100 grain weight $(25.73 \mathrm{~g})$. 100-grain weight was affected significantly by different potassium levels. Application of $200 \mathrm{~kg} \mathrm{ha} \mathrm{kg}^{-1}$ potassium produced the more 100-grain $(28.17 \mathrm{~g})$ weight where as control produced less 100-grain (26.14 g) weight. Potassium application improved the test grain weight not only on optimum but also on early and late planting but this improvement was found statistically non-significant.

The final grain yield is a function of cumulative contribution of its various yield parameters which are influenced by various agronomic practices and environmental conditions. The data pertaining grain yield is given in Tables (I) which revealed that sowing dates significantly influenced the grain yield. Crop sown on $22^{\text {nd }}$ February produced significantly highest grain yield of $5.08 \mathrm{Mg} \mathrm{ha}^{-1}$ where as crop sown on $15^{\text {th }}$ March produced lowest grain yield $\left(4.52 \mathrm{Mg} \mathrm{ha}^{-1}\right)$. Various levels of potassium application also had significant effect on maize grain yield. Application of $200 \mathrm{~kg} \mathrm{ha}^{-1}$ potassium gave significantly the maximum grain yield of $4.93 \mathrm{Mg} \mathrm{ha}^{-1}$ which was statistically at par with the maize grain yield grown by the potassium application@100 kg ha ${ }^{-1}$ where as control produced the minimum grain yield of $4.02 \mathrm{Mg} \mathrm{ha}^{-1}$. Sowing dates $\times$ potassium levels interaction was found to be significant (Table I\&II). Data table showed that highest grain yield was obtained when maize was grown on $22^{\text {nd }}$ February with potassium application of $200 \mathrm{~kg} \mathrm{ha}^{-1}$ and was at par with maize crop sown on $22^{\text {nd }}$ February with potassium application of $100 \mathrm{~kg} \mathrm{ha}^{-1}$ while lowest yield was obtained in case of maize crop grown early ( $1^{\text {st }}$ February) with no potassium application (Table I). Grain crude protein content significantly differed in maize hybrids when sown on different times (Table I). Early sown crop yielded significantly more crude protein contents in grains $(8.05 \%)$ than other sowing dates. Minimum of $7.79 \%$ grain protein contents were produced when crop sown on 15th March. Different levels of $\mathrm{K}$ application also significantly influenced crude protein contents in grains. $\mathrm{K}$ application in all treatments increased crude protein content in grains over control. Maximum crude protein content $(8.07 \%)$ in grains were recorded, where $200 \mathrm{~kg} \mathrm{ha}^{-1}$ potassium was applied, while minimum grain protein contents were observed in controlled plots. Interactive effects between maize sowing dates and $\mathrm{K}$ levels on crude protein content in grains were found non-significant (Table I). Data regarding grain oil contents showed that crude oil content in grains significantly affected by different sowing dates (Table I). Maximum grain oil content of $4.31 \%$ was produced when crop was sown on 1st February which statistically similar oil content $(4.19 \%)$ was observed in maize grains sown on $22^{\text {nd }}$ February. Minimum grain oil content of $4.07 \%$ was recorded when crop was grown on $15^{\text {th }}$ March. $\mathrm{K}$ application in all treatments significantly increased crude oil content in grains over control. Maximum crude oil content in grain was recorded (4.27\%), where $200 \mathrm{~kg} \mathrm{~K} \mathrm{ha}^{-1}$ was applied. Interactive effects of sowing dates and $\mathrm{K}$ levels on crude oil content in grains were, however, non-significant (Table I ).

\section{Economic analysis}

Data regarding economic analysis of potassium application under early and late conditions presented in Table II. Perusal of economic analysis indicated the cost of production, gross income and net income increased with increased potassium application under each sowing regimes but benefit cost ratio (BCR) was improved with potassium application@100 kg ha $^{-1}$ when planted on $1^{\text {st }}$ Feb (Table II). Although potassium improved grain yield under diverse conditions of Faisalabad

Table II. Economic analysis of potassium application in spring sown maize as planted under early and late sown conditions.

\begin{tabular}{|c|c|c|c|c|c|c|}
\hline Sowing dates & $\begin{array}{c}\text { Potassium levels } \\
\qquad\left(\mathrm{kg} \mathrm{ha}^{-1}\right)\end{array}$ & $\begin{array}{l}\text { Grain yield } \\
\left(\mathrm{Mg} \mathrm{ha}^{-1}\right)\end{array}$ & $\begin{array}{c}\text { Cost of } \\
\text { production (Rs.) }\end{array}$ & $\begin{array}{l}\text { Gross income } \\
\quad\left(\text { Rs. ha }{ }^{-1}\right)\end{array}$ & $\begin{array}{l}\text { Net income } \\
\left(\text { Rs. ha- }{ }^{-1}\right)\end{array}$ & $\begin{array}{l}\text { Benefit cost } \\
\text { ratio }(\mathrm{BCR})\end{array}$ \\
\hline \multirow[t]{3}{*}{ 1st February } & 0 & $3.72 \mathrm{e}$ & 29050 & 80460 & 51410 & 2.77 \\
\hline & 100 & $4.9 \mathrm{~b}$ & 36426 & 105770 & 69344 & 2.90 \\
\hline & 200 & $4.94 \mathrm{~b}$ & 43752 & 106480 & 62728 & 2.43 \\
\hline \multirow[t]{3}{*}{ 22ndFebruary } & 0 & $4.79 \mathrm{c}$ & 29050 & 103488 & 74438 & 3.56 \\
\hline & 100 & $5.2 \mathrm{a}$ & 36426 & 112175 & 75749 & 3.08 \\
\hline & 200 & $5.24 \mathrm{a}$ & 43752 & 113043 & 69291 & 2.58 \\
\hline \multirow[t]{3}{*}{ 15th March } & 0 & $3.55 \mathrm{f}$ & 29050 & 76993 & 47943 & 2.65 \\
\hline & 100 & $4.28 \mathrm{~d}$ & 36426 & 92643 & 56217 & 2.54 \\
\hline & 200 & $4.31 \mathrm{~d}$ & 43752 & 93273 & 49521 & 2.13 \\
\hline LSD at 0.05 & & 0.080 & - & - & - & - \\
\hline
\end{tabular}


but its application @ 100 kg ha ${ }^{-1}$ was found economically only under early planting $1^{\text {st }}$ Feb.

Grain yield is the most important determinant in appraising crop productivity, in maize it depends on number of plants per unit area, cobs per plants, grains per cob and grain weight. Crop sown on 22nd February (optimum) recorded maximum grain yield followed by crop sown on 1st February (early) while minimum grain yield was observed in crops sown on 15th March (late). Improvement in grain yield in early and optimum sown spring maize is associated with improved cobs per plant, grains per cob and 100-grain weight. While reduced yield of late planted maize associated with lowered grains as well as grain mass per cob and which could be attributed to short growth duration, heat and moisture stress during pollination. These results are in agreement with those by Otegui and Melon (1997), who reported that delayed plantings are generally accompanied by increased temperatures during the growing season, which accelerate crop development and decrease accumulated solar radiation, resulting in less biomass production, kernel set and grain yield. In this experiment, a progressive increase in potassium application significantly enhanced grain yield at all three planting date (early, optimum and late) and results showed that the efficiency of potassium fertilizer in early and late planting than optimum planting (Table 1). Application of $200 \mathrm{~kg} \mathrm{~K}_{2} \mathrm{O}$ ha $^{-1}$ produced significantly higher grain yield which was statistically at par with grain yield obtained by applying $100 \mathrm{~kg} \mathrm{~K}_{2} \mathrm{O} \mathrm{ha}^{-1}$ where as control produced the minimum grain yield in all planting dates. This increased in grain yield as a result of potassium application during early and late planted spring maize may be due to mitigating adverse effect of chilling in early and high temperature accompanied drought stress in late sown and inducing the prolificacy of grains per cob and grain weight. Numerous studies have been shown that application of potassium fertilizer mitigates the adverse effect of drought on growth and grain yield in Brassica species (Fanaei et al., 2009) and maize (Pettigrew, 2008). These results are in conformity with findings of Pettigrew (2008) and Witt and Pasquin (2007) who reported that K application increased grain yield due to increase in prolificacy, number of grains per cob and grain weight.

Data (Table I) indicated that different planting date did not affect the cobs per plant significantly. The increase in cobs per plant by potassium application was probably due to its influence on various enzymatic activities which controlled the flowering and seed formation. These results are in accordance with those of Boris et al. (2004) and Gamboa et al. (1990) who stated that K application increased prolificacy probably due to availability of more nutrients to plants.
Grains per cob are an important yield component and index of synchronous fertilization. Early and optimum planted maize produced statistically similar grains per cob; however, lower grains per cob were produced in late sown maize which was associated with asynchronous and partial fertilization as a result of high temperature accompanied water deficit during anthesis. The yield reduction in kernel number has been proposed to be due to a number of factors including lack of pollination, abortion of ovule prior to fertilization and abortion of fertilized kernels (Bassetti and Westgate, 1993). High temperature accompanied with water stress between 2-22 days after silking was impacted negatively on pollen viability (Lafittee, 2000) which ultimately determined kernel number (Monjardino et al., 2006), while potassium application raised grain's number per cob by improving pollen viability through mitigating the adverse effects of high temperature. These results are in conformity with the findings of Polerecky (1980) and Mulkey and Pietsch (1980) who claimed that K application increased the number of grains per cob.

Early and optimum planted maize produced statistically similar grain weight than late sown maize which may associated with lower assimilates partitioning toward grain subjected to atmospheric conditions of high temperature accompanied with decreased translocation of assimilates from source to sink (developing grain). Previously, Zinselmeier et al. (1995) reported that grain weight was most sensitive to abiotic stress during grain formation which limiting assimilates flow toward developing grain (Lee and Tollenarar, 2007). However, potassium application improved grain weight in this experiment through mitigating adverse effect of high temperature on cell number and size in young ovules and was marked by rapid grain expansion and might be related to the low levels of metabolic activities within developing grain. These results are supported with those of Cheema et al. (1999), Mangel and Kirkby (1987) in maize and Sharma et al. (2005) in wheat who reported that potassium resulted to increase in kernel weight through regulating enzymatic activities and translocation of photosynthates.

Early sown crop yielded significantly higher grain protein contents than optimum and late. The higher protein content in grain produced by early planting was due to favorable temperature during grain formation which is suitable for protein biosynthesis. Particularly, high temperature has a negative impact on kernel growth, kernel mass and protein accumulation (Monjardino et al., 2006). Significant decrease in protein contents was found in late sowing when compared to optimum and early sown maize. Fabijanac et al. (2006) reported no significant effect of growing season 
on the protein content of maize. But potassium fertilization progressively increased grain protein content at different sowing dates (Table I). Improvement in grain protein contents may be due to higher $\mathrm{K}$ availability to maize plants, which involved in ATPs synthesis that is pre-requisite for translocation of $\mathrm{N}$-uptake and protein biosynthesis (Tisdale et al., 1997). These results are in line with the findings of the Mahmood et al. (2000) and Pettigrew (2008) who reported that $\mathrm{K}$ application increased crude protein contents in maize grains. $\mathrm{K}^{+}$impacts the underlying physiological processes that determine crop yield and quality production. $\mathrm{K}$ involvement is crucial for protein synthesis processes, beginning with enzyme activation and continuing through ribosome synthesis and mRNA turnover (Evans and Wildes, 1971).

Grain oil contents were influenced by different sowing dates. Significant increase in oil contents was found in earlier planted compared to optimum and late planted maize (Table I) and these results are supported with findings of Fabijanac et al. (2006) who also found that early sown crop resulted in higher crude oil contents than late sown. Potassium application increased grain oil contents at all sowing dates which was in agreement with the findings of Mahmood et al. (2000) who also reported that K application increased crude oil content in grains. The possible reason might be the involvement of the two enzymes in the pathway of fatty acid biosynthesis viz., acetyl- Co A synthetase and acetyl-Co A carboxylase. The former is activated by $\mathrm{K}^{+}$, while small changes in $\mathrm{K}^{+}$and $\mathrm{Mg}^{+2}$ concentrations have been reported to produce large changes in the activity of the wheat germ acetyl-Co A carboxylase (Nicolson et al., 1979).

\section{Conclusion}

Late sown spring faced heat stress caused asynchronous pollination and poor grain formation but early sowing of the crop seems an ideal solution to escape from heat spell but potassium application improved crop stand and yield through increasing number and size of grain by counteracting the chilling and heat stress effects even at early and late sown condition. The economic analysis showed that $100 \mathrm{~kg} \mathrm{ha}^{-1}$ potassium application can beneficial only under early planting on $1^{\text {st }}$ February (Table II).

\section{References}

Ahmad I, Basra SMA, Hussain S, Hussain SA, Hafeez-Ur-Rehman, Rehman A and Ali A (2015), Priming with ascorbic acid, salicylic acid and hydrogen peroxide improves seedling growth of spring maize at suboptimal temperature, Journal of Environmental and Agricultural Sciences 3: 14-22.

Ahmad I, Basra SMA and Wahid A (2013), Exogenous application of ascorbic acid, salicylic acid and hydrogen peroxide improves the productivity of hybrid maize at low temperature, Internal Journal of Agriculture and Biology 16: 825-830.

Apel K and Hirt H (2004), Reactive oxygen species: metabolism, oxidative stress and signal transductions, Annual Review of Plant Biology 55: 373-399.

Balasubramian P and Palaniappan SP (2001), Principle and practices of Agronomy, Agrobios (India), Johdpur, India, pp 21-24.

Bassetti P and Westgate ME (1993), Emergence, elongation and senescence of maize silks, Crop Science 33: 271-275.

Boris V, Syecnjak Z, Knezevic M and Grbesa D (2004), Performance of prolific and non prolific hybrids under reduced input and high input cropping systems, Field Crops Research 90: 203-212.

Brar MS and Singh R (1995), Potassium depletion and effects of $\mathrm{K}$ fertilization on soil $\mathrm{K}$ content, growth and $\mathrm{K}$ concentration of maize, Journal of Potassium Reseach 11: 154-159.

Chawdhary SI and Wardlaw IF (1978), The effect of temperature on kernel development in cereals, Australian Journal Agricultural Research 29: 205-223.

Cheema MA, Iqbal M, Cheema ZA, Ullah B and Rafique M (1999), Response of hybrid maize to potassium, International Journal of Agriculture Biology 1: 267-269.

CIMMYT (1988), An Economic Training Handbook, Economic Programme, CIMMYT, Mexico.

Cohn MA and Obendorf RL (1978), Occurrence of stellar lesion during imbibitional chilling of Zea mays L., American Journal of Botany 65: 50-56.

Davis JG, Walker ME, Parker MB, and Mullinix B (1996), Long term phosphorus and potassium application to corn on Coastal Plain Soils, Journal of Production Agriculture 9: 88-94.

Evans HJ, and Wildes RA (1971), Potassium and its role in enzyme activation In: Potassium in Biochemistry and Physiology, International Potash Institute, Bern, Switzerland. 
Fabijanac D, Varga B, Svecnjak Z and Grebsa D (2006), Grain yield and quality of semiflint maize hybrids at two sowing dates, Agriculturae Conspectus Scientificus 71: 45-50.

Fanaei HR, Galavi M, Kafi M and Bonjar AG (2009), Amelioration of water stress by potassium fertilizer in two oilseed species, International Journal of Plant Production 3: 41-54.

Gamboa D, Perez FR and Arevalo CG (1990), Sweet corn evaluation of cultivars introduced by the E.E.A.D.C., Advance agro-industrial 1: 23-24.

Greaves JA (1996), Improving suboptimal temperature tolerance in maize: the research for variance, Journal of Experimental Botany 47: 307-323.

Harrison L, Michaelsen J, Funk C and Husak G (2011), Effects of temperature changes on maize production in Mozambique, Climatic Research 46: 211-222.

Hola D, Longrova KM, Kocova M and Rotova O (2003), Photosynthetic parameters of maize (Zea mays L.) inbred line and F1 hybrids: their different response to and recovery from rapid or gradual onset of low temperature stress, Photosynthica 41: 429-442.

Jackson ML (1962), Soil chemical analysis, Constable and Co. Ltd., London, p 129.

Janda T, Szalai G, Kissimon IJ, Paldi E, Marton C and Szigeti Z (1994), Role of irradiance in the chilling injury of young maize plants studied by chlorophyll florescence induction measurements, Photosynthetica 30: 293-299.

Johnson R and Herrero MP (1981), Corn pollination under moisture and high temperature stress, Proceedings of the corn and sorghum industry research conference, Chicago, II American Seed Trade Association, Washington DC, pp 66-77.

Kemmler G and Krauss A (1987), Potassium and stress tolerance: Potassium and fertilizer use efficiency, Proceedings of the workshop on the role of potassium in improving fertilizer use Efficiency NFDC, Islamabad, 21-22 March 1987 In: Potassium and fertilizer use efficiency, 1989, NFDC, Planning and Development Division, Government of Pakistan, Islamabad, pp 187-202.

Knudsen D, Peterson GA and Pratt PF (1982), Lithium, sodium and potassium In: Methods of Soil Analysis,
Part 2. Chemical and Microbiological Properties, Agronomy Monograph No. 9, Eds. Page AL, Miller RH and Keeney DR, $2^{\text {nd }}$ Ed., SSSA, Madison, WI, pp 225-246.

Lafittee HR (2000), Abiotic stresses affecting maize In: Tropical Maize: Improvement and Production, Food and Agriculture Organization of the United Nations, Rome, Eds. Paliwal RL, Granados G, Lafitte HR and Vlollc AD, pp 93-103.

Lee EA and Tollenaar M (2007), Physiological basis of successful strategies for maize grain yield, Crop Science 47: 202-215.

Low NH (1990), Food analysis, 417/717. Laboratory manual Dept. of Applied Microbiology and Food Science, University of Saskatchewan, Canada, pp 37-38.

Mahmood T, Saeed M and Ahmad R (2000), Impact of water and potassium management on yield and quality of maize, Pakistan Journal of Biological Sciences 3: 531-533.

McLean EO (1982), Soil $\mathrm{pH}$ and lime requirement In: Methods of Soil Analysis. Part 2. Chemical and Microbiological Properties, Agronomy Monograph No. 9, Eds. Page AL, Miller RH and Keeney DR, $2^{\text {nd }}$ Ed., SSSA, Madison, WI, pp 199-224.

Meille LJ and Pellerrin S (2008), Shoot and root growth of hydroponic maize as influenced by K deficiency, Plant Soil 304: 157-168.

Mengal K and Kirkby EA (1987), Principle of plant Nutrition, $4^{\text {th }}$ Ed., International Potash Institure, Bern, Switzerland, pp 434-440.

Mitchell JC, and Petolino JF (1988), Heat stress effects on isolated reproductive organs of maize, Journal of Plant Physiology 133: 625-628.

Monjardino P, Smith AG and Jones RJ (2006), Zein transcription and endoreduplication in maize endosperm are differentially affected by heat stress, Crop Science 46: 2581-2589.

Mulkey JR and Pietsch D (1980), Corn hybrid performance, Uvalde, Texas-1979, Pub. Texas Agri. Expt. Stat., No. PR 3654: p 10.

Nicolson NC, Adee A and Stump PK (1979), Fat metabolism in higher plants: Further characterization of wheat germ acetyl- Co A carboxylase, Archieve Biochemistry 192: 445-456. 
Noctor G and Foyor CH (1998), Ascorbate and glutathione: keeping active Oxygen under control, Annual Review of Plant Physiology and Molecular Biology 49: 249-279.

Olsen SR and Sommers LE (1982), Phosphorus In: Methods of Soil Analysis. Part 2. Chemical and Microbiological Properties, Agronomy Monograph No. 9, Eds. Page AL, Miller RH and Keeney DR, $2^{\text {nd }}$ Ed., SSSA, Madison, WI, pp 403-430.

Otegui ME and Melon S (1997), Kernel set and flower synchrony within the ear of maize: I. Sowing date effects, Crop Science 37: 441-447.

Peter LP and Young VR (1980), Nutritional evaluation of protein foods, The United Nation University, Japan, p 8.

Pettigrew WT (2008), Potassium influences on yield and quality production for maize, wheat, soybean, and cotton, Physiologia Plantarum 133: 670-681.

Polerecky O (1980), New maize hybrids and their yield parameters, RostlinnaVyroba 26: 113-114.

Prasad PVV and Staggenborg SA (2008), Impacts of drought and /or heat stress on physiological, developmental, growth and yield of crop plant In: Response of crops to limited water: understanding and modeling water stress effects on plant growth processes, Eds. Ajuha LR, Reddy VR, Saseendran SA and Yu Q, American Society of Agronomy/ Crop Science Society of America/ Soil Science Society of America, Madison, WI, pp 301-356.

Ramadoss M, Birch CJ, Carberry PS and Roberston M (2004), Water and high Research Unit / CSIRO, Toowoomba, QLD 4350.

Rhoades JD (1982), Cation exchange capacity. In: Methods of Soil Analysis. Part 2. Chemical and Microbiological Properties, Agronomy Monograph No. 9, Eds. Page AL, Miller RH, Keeney DR, $2^{\text {nd }}$ Ed., SSSA, Madison, WI, pp 149-157.

Rodriguez A, Butron G, Sandoy G, Ordas A, Revilla P (2007), Combining maize base germplasm for cold tolerance breeding, Crop Science 47: 1467-1473.

Ryan J, Estefan G and Rashid A (2001), Soil and plant analysis laboratory manual, ICARDA, Aleppo, Syria.

Schoper JB, Lambert RJ and Vasilas BL (1986), Maize pollen viability and ear receptivity under water and high temperature stress, Crop Science 26: 1029-1033.
Sharma S, Duveillier E, Basnet R, Karki CB and Sharma RC (2005), Effect of potash fertilization on Heliinthosporium leaf blight severity in wheat and associated increases in grain yield and kernel weight, Field Crops Research 93: 142-150.

Steel RGD, Torrie TH and Dickey DA (1997), Principles and Procedures of Statistics: A Biometrical Approach $3^{\text {rd }}$ Ed., McGraw Hill Book International Co. Inc., Singapore, pp 204-232.

Stewart CR, Martin BA, Reding L, Cenvick S (1990), Seedling growth, mitochondrial characteristics and alternative respiratory capacity of corn genotypes differing in cold tolerance, Plant Physiol 92: 761-766.

Tecator AB (1981), Determination of Kjeldahl nitrogen content with Kjeltecautosystems I, II, III and IV, Tecator ApplicationNote AN 30/81, Tecator Inc., USA.

Tisdale SL, Nelson WL and, Beaton JD (1990), Soil Fertility and Fertilizers: Elements required in plant nutrition, $4^{\text {th }}$ Ed., Maxwell McMillan Publishing, Singapore, pp 52-92.

Tisdale SL, Nelson WL, Beaton JD and Havlin JL (1997), Soil Fertility and Fertilizers: Elements required in plant nutrition, $5^{\text {th }}$ Ed., Prentice Hall of India (Pvt.) Ltd., New Dehli, India. pp 68-96.

Witt C and Pasuquin JMCA (2007), Improving the productivity and profitability of maize in Southeast Asia V. E-Int. Fert. Corres. Vol. 14, pp-14-15.

Zinselmeier C, Westgate ME, Schussler JR, Jones RJ (1995), Low water potential disrupts carbohydrate metabolism in maize (Zea mays L.) ovaries, Plant Physiology 107: 385-391.

Received: 04 October 2016; Revised: 14 May 2017;

Accepted: 29 May 2017. 